\title{
Characterization and Modification of a Clay Mineral Used in Adsorption Tests
}

\author{
Natália Costa Dias, Patrícia Arns Steiner, Maria Cristina Borba Braga* \\ Water Resources and Environmental Engineering Post-Graduate Program, Department of Hydraulics and Sani- \\ tation, Parana Federal University, Curitiba, Brazil \\ Email: *crisbraga@ufpr.br
}

Received 28 May 2015; accepted 8 June 2015; published 12 June 2015

Copyright (C) 2015 by authors and Scientific Research Publishing Inc.

This work is licensed under the Creative Commons Attribution International License (CC BY). http://creativecommons.org/licenses/by/4.0/

(c) () O) Open Access

\begin{abstract}
Clay minerals are widespread in natural systems and have been widely used for the removal of pollutants. In this study, natural expanded vermiculite was used in adsorption tests to remove ammonium nitrogen from landfill leachate. The modification of vermiculite was carried out using $\mathrm{NaOH}$ and $\mathrm{HCl}$, and for both modifications the best concentration was $0.1 \mathrm{~mol} / \mathrm{L}$. The results produced by XRD (X-ray diffraction) showed that Al replaced $K$ after modification of the vermiculite using $\mathrm{HCl}$ and that $\mathrm{Mg}$ and $\mathrm{Na}$ replaced $\mathrm{K}$ after modification using $\mathrm{NaOH}$. It was observed that the adsorption capacity increased as the percentage in mass of $\mathrm{K}$ diminished. The Langmuir is the isotherm that presents the best fit of the data, and the values of $R_{L}$ (the Langmuir coefficient) suggest that the adsorption is linear. The thermodynamic parameters indicate that the process is spontaneous and endothermic, that there is a high affinity between the adsorbate and the adsorbent, and that physical adsorption is prevalent.
\end{abstract}

\section{Keywords}

Adsorption Isotherms, Adsorption Thermodynamics, Clay Minerals, Expanded Vermiculite, Landfill Leachate, Vermiculite

\section{Introduction}

Adsorbents are solid particles that present porous structure and volume of pores up to $50 \%$ of the total volume of particles, which justify their use in adsorption processes. Various materials can be used as adsorbents, such as activated carbon, silica gel (sodium silicate and sulfuric acid), activated alumina, zeolite (aluminum silicate), vermiculite (aluminum-iron-magnesium silicate, and phyllosilicate), bentonite (aluminum phyllosilicate), and

\footnotetext{
"Corresponding author.
}

How to cite this paper: Dias, N.C., Steiner, P.A. and Braga, M.C.B. (2015) Characterization and Modification of a Clay Mineral Used in Adsorption Tests. Journal of Minerals and Materials Characterization and Engineering, 3, $277-288$. 
organic and synthetic polymers [1].

Vermiculite is found in various parts of the world, but currently the major mines are located in South Africa, China, Brazil, Zimbabue and the United States. Vermiculite clays are weathered micas (Figure 1 and Figure 2) with structural formula $\left.\left\{(\mathrm{Mg}, \mathrm{Fe})_{3}\left[(\mathrm{Si}, \mathrm{Fe}, \mathrm{Al})_{4} \mathrm{O}_{10}\right][\mathrm{OH}]_{2} 4 \mathrm{H}_{2} \mathrm{O}\right)\right\}$ in which the potassium ions among molecular sheets are replaced by magnesium and iron ions [2]-[4]. Aluminum, hydrogen, magnesium and oxygen are essential elements, whereas calcium, sodium and potassium are common impurities [5]. Table 1 and Table 2 present some physical and chemical characteristics of vermiculite.

Expanded vermiculite is obtained by exfoliation or thermal expansion that consists of heating the natural mineral to a temperature ranging from $540^{\circ} \mathrm{C}$ to $810^{\circ} \mathrm{C}$. The exfoliation process converts the dense flakes of ore into lightweight and porous granules [5]. In its expanded form, vermiculite is chemically active and biologically inert [8] [9].

The adsorption capacity of metals by vermiculite has been studied. The cationic exchange capacity (CEC) is one of the factors that characterizes the adsorption capacity of ions. Amongst the mechanisms that can be related to the adsorption of metal ions onto vermiculite is the cationic exchange that occurs on the planar sites. This exchange is the result of the interaction between the metal ions and the outer-sphere complexes [10] [11]. However, as a result of competitiveness, which is a function of the affinity amongst the ions and the vermiculite, the adsorption of some ions may result in the reduction of the adsorption capacity of others. According to the results found by the authors who studied the CEC of vermiculite, values varied from $40 \mathrm{meq} / 100 \mathrm{~g}$ to $250 \mathrm{meq} / 100 \mathrm{~g}$ [12]-[15]. Barshad [14] studied the competition between $\mathrm{K}$ and $\mathrm{NH}_{4}{ }^{+}$, and found out that the adsorption onto vermiculite was proportional to the CEC.

Other authors studied the vermiculite as an agent of adsorption of ions, in particular metal ions, for instance, results produced by Foscolos [12]. This author determined the equilibrium constants of $\mathrm{H}^{+}, \mathrm{Na}^{+}, \mathrm{K}^{+}, \mathrm{Mg}^{2+}, \mathrm{Ca}^{2+}$ and $\mathrm{Al}_{3}{ }^{+}$, using five different concentrations of $\mathrm{HCl}, \mathrm{NaCl}, \mathrm{MgCl}_{2}$ and $\mathrm{CaCl}_{2}$, and pointed out that there was a hierarchic organization among the studied ions: $\mathrm{Mg}^{+}<\mathrm{Ca}^{2+}<\mathrm{H}^{+}<\mathrm{Al}^{3+}<\mathrm{Na}^{+}$. Thus, the author concluded that $\mathrm{Na}^{+}$was the ion that presented the greatest capacity of reposition on the surface of vermiculite, and that $\mathrm{K}^{+}$also could present a high capacity of reposition. On the other hand, Abollino et al. [13] observed that the capacity of metal retention by vermiculite presented the following order: $\mathrm{Pb}^{2+}<\mathrm{Cu}^{2+}<\mathrm{Cd}^{2+}<\mathrm{Zn}^{2+}<\mathrm{Ni}^{2+}<\mathrm{Mn}^{2+}$. According to these authors, this hierarchy is a function of the chemical properties of the ions and not of the characteristics of the vermiculite. These authors also concluded that the vermiculite could be effectively utilized as an adsorbent for the treatment of high ionic strength wastewaters and high $\mathrm{pH}$. It was also mentioned that the vermiculite could be used to treat low salinity solutions in any $\mathrm{pH}$ value.

The use of expanded vermiculite as a supporting agent to wastewater treatment has been presented in the literature. The use of expanded vermiculite as adsorbent has been particularly related to the removal of dyes, hydrocarbons and other hydrophobic substances [16]-[22].

Adsorbents can be modified by various means, and the objective is to increase their adsorption capacity. This increase can be obtained by intensifying the linkage strength between the adsorbent and the adsorbate, substituting a cation with higher affinity to the adsorbate, increasing the porosity of the adsorbent, increasing the specific surface area and activating the adsorbent. Acidic, basic, pillaring and hydrothermal treatments are ways to modify adsorbents [23]-[29].

Adsorption is a transfer process of a substance (adsorbate) that is in solution in a liquid phase to the surface of a solid phase (adsorbent). The adsorption process can occur by means of physical forces, in which the van der Walls forces are involved. It can also occur by means of chemisorption, which involves chemical interaction between the adsorbate molecules and the surface of the adsorbent [1].

In the adsorption process, the isotherm represents the equilibrium relationship between the concentration in the liquid phase and the concentration on the adsorbent at a given temperature. The isotherm provides information to evaluate the affinity and the adsorption capacity of an adsorbent by an adsorbate [30]. In order to produce the best evaluation, the models most frequently used are those of Langmuir and Freundlich. The Langmuir isotherm model considers that the adsorption is restricted to a monolayer, and it is assumed that the surface of the pores of the adsorbent is homogeneous. One important feature of this model is the consideration that the forces of interaction amongst the adsorbed molecules are negligible and that the adsorption is reversible [1] [31]. The separation factor is the main characteristic of the Langmuir isotherm ( $R_{L}-$ the Langmuir coefficient). This coefficient is dimensionless and inversely proportional to the highest initial concentration of the adsorbate [31]. The results produced by the calculation of the Langmuir coefficient allow evaluating the adsorption process in terms 


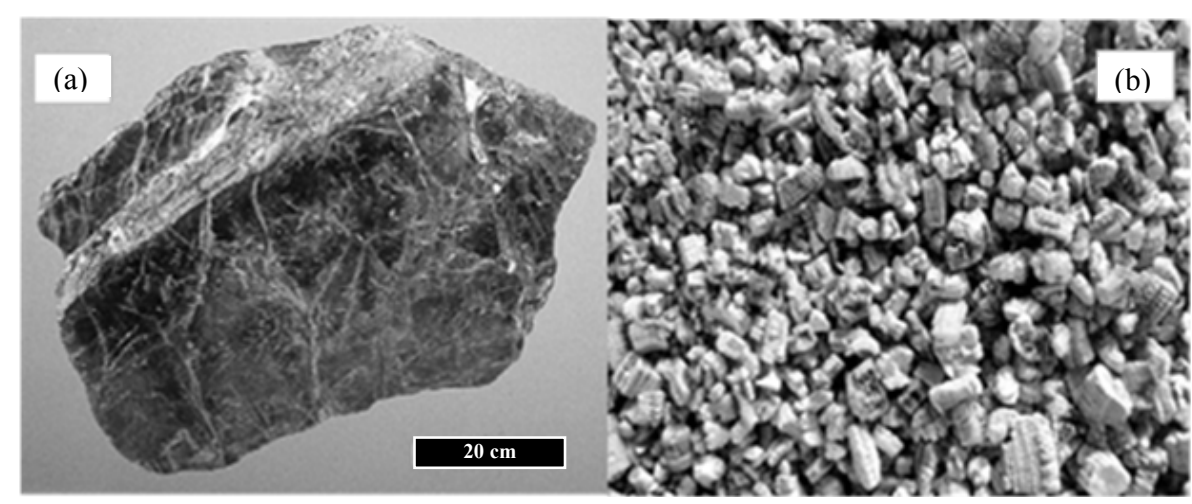

Source: (a) Vermiculite Mineral Data [6]; (b) the author.

Figure 1. Vermiculite (a) natural raw; (b) natural expanded.

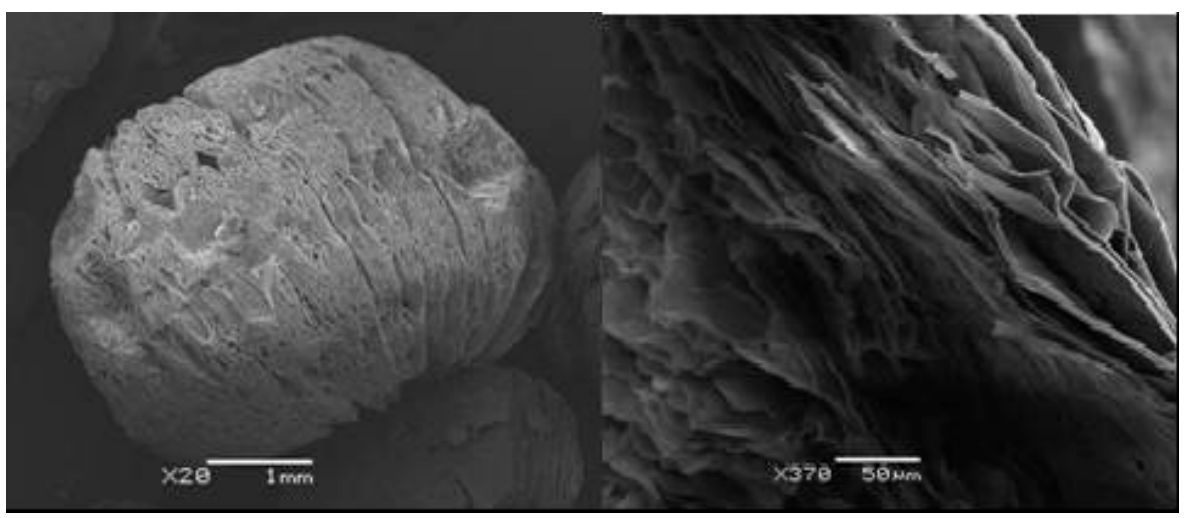

Source: The author.

Figure 2. Scanning electron micrograph of the expanded vermiculite.

Table 1. Properties of exfoliated vermiculite.

\begin{tabular}{cccc}
\hline Property & Typical data & Property & Typical data \\
\hline color & light to dark brown & combustibility & non combustible \\
bulk density & $64-160 \mathrm{~kg} / \mathrm{m}^{3}$ & Mohs hardness & $1-2(2.1-2.8)[3]$ \\
specific gravity & $2.5 \mathrm{~g} / \mathrm{cm}^{3}[3]$ & cation exchange capacity & $50-100 \mathrm{meq} / 100 \mathrm{~g}$ \\
moisture loss at $110^{\circ} \mathrm{C}$ & $4 \%-10 \%$ & waterholding capacity & $220 \%-325 \%$ (by weight) \\
pH in water & $6-9$ & thermal conductivity at $25^{\circ} \mathrm{C}$ & $60 \%-50 \%$ cal $/ \mathrm{m}^{2} \cdot \mathrm{h}^{\circ} \mathrm{C}[3][4]$ \\
\hline
\end{tabular}

Note: ${ }^{a}$ Bulk density and water holding capacity vary with grain size; ${ }^{b}$ Exchangeable ions are $\mathrm{Mg}^{2+}$ and $\mathrm{Ca}^{2+}$ (sodium acetate saturation/ammonium acetate substitution method). Source: Adapted from The Vermiculite Association (2014) [7].

Table 2. Typical chemical analysis.

\begin{tabular}{cccc}
\hline Component & Percent by weight & Component & Percent by weight \\
\hline $\mathrm{SiO}_{2}$ & $38-46$ & $\mathrm{Fe}_{2} \mathrm{O}_{3}$ & $6-13$ \\
$\mathrm{Al}_{2} \mathrm{O}_{3}$ & $10-16$ & $\mathrm{TiO}_{2}$ & $1-3$ \\
$\mathrm{MgO}$ & $16-35$ & $\mathrm{H}_{2} \mathrm{O}$ & $8-16$ \\
$\mathrm{CaO}$ & $1-5$ & Other & $0.2-1.2$ \\
$\mathrm{~K}_{2} \mathrm{O}$ & $1-6$ & & \\
\hline
\end{tabular}

Source: The Vermiculite Association (2014) [7]. 
of the favorability of occurrence, linearity and reversibility. If $R_{L}$ values vary from zero to the unit $\left(0<R_{L}<1\right)$, the adsorption process is favorable; if it is higher than the unity $\left(R_{L}>1\right)$, it is unfavorable; if it equals the unit $\left(R_{L}=1\right)$, it is linear; if it equals zero $\left(R_{L}=0\right)$, it is irreversible. The Freundlich isotherm model establishes that there is no limit for the adsorption capacity of the adsorbent, and that it is because the amount adsorbed tends to infinite when the concentration of the solution increases. This model is often the most frequently used for the description of the adsorption characteristics of wastewater treatment [1]. The characteristics of the Freundlich isotherm are expressed in terms of intensity of the adsorption process (" $n$ "). The results using this variable allow evaluating if chemical $(n<1)$ or physical $(n>1)$ adsorption is prevalent [31] [32].

According to Castilla [33], when there are more than one adsorbent to choose, the adsorption isotherms represent a tool to identify the one that is most adequate for one particular condition.

Another fundamental condition to the evaluation of the adsorption process is the determination of the thermodynamic parameters, Gibbs free energy variation $\left(\Delta G^{0}\right)$, enthalpy $\left(\Delta H^{0}\right)$ and entropy variation $\left(\Delta S^{0}\right)$. The results produced by the calculation of these parameters are of great importance to understand whether an adsorbent presents characteristics to carry out the adsorption process. On one hand, if negative values of $\Delta G^{0}$ are obtained, there is an indication that the adsorption process is spontaneous. On the other hand, if positive values of $\Delta H^{0}$ are obtained, there is an indication that the process is endothermic. These results are associated with the understanding that the adsorption capacity increases with an increase in the temperature. However, one of the most significant results is referred to the association between values of entropy and Gibbs free energy. If positive values of $\Delta S^{0}$ are associated with negative values of $\Delta G^{0}$, there is an indication that there is a high affinity between the adsorbent and the adsorbate [34]-[36].

Notwithstanding, information on the adsorption kinetics is relevant because as a result of kinetic experiments the time to reach the equilibrium will be determined. This information is of fundamental importance for the determination of the adsorption isotherms [37].

This research was focused on the evaluation of a Brazilian clay mineral, natural expanded vermiculite. To reach the goal, the chemical characteristics of the vermiculite were determined, and the adsorption characteristics of the adsorbent were also determined in order to assess its capability to remove ammonium nitrogen from landfill leachate.

\section{Materials and Methods}

The important remarks related to the methods used to characterize both the vermiculite and the adsorption process are presented hereafter.

\subsection{Chemical Characterization of Expanded Vermiculite}

The characteristics of expanded vermiculite were determined by Energy-dispersive X-ray spectroscopy and also by X-ray diffraction, as presented below.

1) Energy-dispersive $X$-ray spectroscopy (EDS)

EDS tests were carried out in a Jeol JSM-636OLV electronic microscope. Samples of expanded natural vermiculite, before and after washing, were oven-dried at $40^{\circ} \mathrm{C}$ for 24 hours and stored in a vacuum desiccator. Subsequently, 5 grains of expanded vermiculite were placed on aluminum support and metalized with golden powder in a Balzer Union FL 9496 (SCD 030) Critical Point Dryer, under the pressure of 0,1 mbar.

The software Noran System Six was used to determine the atomic percentage of each analyzed sample.

2) X-ray diffraction (XRD)

In order to carry out the XRD analysis a sample of expanded vermiculite was pulverized in a container coated with tungsten carbide. Subsequently, a $7 \mathrm{~g}$-sample from the pulverized material mixed with $1.4 \mathrm{~g}$ of organic wax was used to produce tablets. For the determination of the chemical composition of the expanded vermiculite these tablets were placed in a Philips-Panalytical PW 2400 equipment, operating with a Rhodium X-ray source of $3 \mathrm{~kW}$.

\subsection{Modification of Expanded Vermiculite}

According to the methodology proposed by Okada et al. (2005) [25], basic and acidic media were used for the modification of expanded vermiculite. 
The modification of the expanded natural vermiculite was carried out using three different concentrations of sodium hydroxide $(\mathrm{NaOH})$ and hydrochloric acid $(\mathrm{HCl})(0.1 \mathrm{~mol} / \mathrm{L}, 1 \mathrm{~mol} / \mathrm{L}$ and $2 \mathrm{~mol} / \mathrm{L})$. The experiments were carried out at room temperature and at $60^{\circ} \mathrm{C}$, the samples were continuously stirred, and the contact time was 2 hours. After each treatment, the expanded vermiculite was washed five times with distilled and deionized water, and oven-dried at $40^{\circ} \mathrm{C}$ in a porcelain dish.

\subsection{Adsorption Experiments}

Adsorption tests were carried out with samples of landfill leachate collected from the treatment system of Curitiba's Sanitary Landfill, Paraná, Brazil (25³7'29.98"S; 49²0'01.66"W).

The adsorption capacity of ammonium nitrogen from landfill leachate onto expanded vermiculite at three temperatures $(288 \mathrm{~K}, 296 \mathrm{~K}, 303 \mathrm{~K})$ was determined using natural expanded and modified adsorbent as well.

Tests for the determination of adsorption isotherms and thermodynamic characteristics were carried out only for the natural expanded vermiculite. After each step of the assay, the concentrations of ammonium nitrogen were determined.

All tests were carried out in triplicate. Blank samples composed of vermiculite and deionized water were processed under the same experimental conditions.

Batch tests

The adsorption batch tests consisted of transferring $50 \mathrm{~mL}$ of leachate and $0.83 \mathrm{~g}$ of natural expanded and modified vermiculite to Erlenmeyer flasks, covered with three layers of Parafilm ${ }^{\circledR}$ and placed in an orbital shaker (Tecnal TE-421). The rotational speed in which the equipment operated was $150 \mathrm{rpm}$. These conditions were adopted for the determination of the type of vermiculite to be used in the tests. For the determination of ammonium nitrogen concentrations samples were collected every 2 hours, for 24 hours, and filtered through qualitative filter paper $(0.205 \mathrm{~mm}, 80 \mathrm{~g} / \mathrm{m})$. These concentrations were determined according to the method 4500 $\mathrm{NH}_{3} \mathrm{~F}$. Phenate Method [38]. Subsequently, the mass of solute adsorbed per mass of adsorbent at equilibrium $\left(q_{\text {eq }}\right)$, in $\mathrm{mg} / \mathrm{g}$, was calculated using Equation (1).

$$
q_{\mathrm{eq}}=\frac{\left(C_{0}-C_{\mathrm{eq}}\right)}{M} V
$$

where, $C_{\mathrm{eq}}$ is the final adsorbate concentration in solution at equilibrium $(\mathrm{mg} / \mathrm{L})$.

\subsection{Langmuir and Freundlich Isotherms Determination}

Five dilutions of raw leachate were used (130 mg/L; $340 \mathrm{mg} / \mathrm{L} ; 760 \mathrm{mg} / \mathrm{L} ; 1200 \mathrm{mg} / \mathrm{L} ; 1700 \mathrm{mg} / \mathrm{L})$ for the determination of adsorption isotherms of ammonium nitrogen onto expanded vermiculite. For each experiment, a $100 \mathrm{~mL}$-diluted leachate sample was transferred to Erlenmeyer flasks containing $3.33 \mathrm{~g}$ of expanded vermiculite, covered with three layers of Parafilm ${ }^{\circledR}$ and placed in an orbital shaker (Tecnal TE-421). The rotational speed in which the equipment operated was $50 \mathrm{rpm}$ for 10 hours, or the equilibrium time determined by adsorption kinetics experiments. The amount adsorbed at equilibrium $\left(q_{\mathrm{eq}}\right)$, in $\mathrm{mg} / \mathrm{g}$, was calculated using Equation (1).

The isotherms experimental data were modeled by linear regression using the Langmuir and Freundlich models (Equation (2) and Equation (3)).

$$
\begin{gathered}
\ln \frac{q_{e}-q_{t}}{q_{e}}=-k_{1} t \\
q_{e}=K_{F} C_{e}^{1 / n}
\end{gathered}
$$

After de determination of the equilibrium data, the statistical parameter SS (Sum of Squares) Equation (4) was applied to identify the model that presented the best fit of the data.

$$
\mathrm{SS}=\frac{1}{n} \sqrt{\sum_{i=1}^{n}\left(q_{\text {téórico }}-q_{\text {experimental }}\right)^{2}}
$$

\subsection{Adsorption Thermodynamics}

Data on concentration and adsorption capacity at equilibrium $\left(q_{\mathrm{eq}}\right)$ were used for the calculation of the ther- 
modynamic parameters of the adsorption process, Gibbs Free Energy $\left(\Delta G^{0}\right)$, internal energy variation $\left(\Delta H^{0}\right)$ and entropy variation $\left(\Delta S^{0}\right)$. The assessment and estimation of the thermodynamic characteristics were based on information presented in Table 3.

The thermodynamic parameters $\Delta G^{0}, \Delta H^{0}$ and $\Delta S^{0}$ are related through the fundamental equation of thermodynamics (Equation (5)).

$$
\Delta G^{0}=\Delta H^{0}-T \Delta S^{0}
$$

The variation of the Gibbs free energy was calculated by Equation (6), whereas the Van't Hoff Equation (7), produced by the combination of Equation (5) and Equation (6), and related to the equilibrium constant $K_{a}$, was used to calculate the internal energy variation and the entropy variation.

$$
\Delta G_{\text {ads }}=-R T \ln K_{a}
$$

where, $T$ is temperature (K), $R$ is the constant of ideal gases $(8.314 \mathrm{~J} / \mathrm{mol} . \mathrm{K})$ and $K_{a}$ is the thermodynamic equilibrium constant.

$$
\ln K_{a}=\frac{\Delta S^{0}}{R}-\frac{\Delta H^{0}}{R T}
$$

\section{Results and Discussion}

\subsection{Characterization of Expanded Vermiculite}

Table 4 presents the results produced by EDS for the chemical characteristics of the expanded vermiculite used to carry out adsorption tests.

As it can be observed from the data presented in Table 4, washing with distilled and deionized water is recommended prior to the use of vermiculite when the matrices present nitrogen and/or phosphorus. Otherwise, the

Table 3. Adsorption characteristics as a function of thermodynamic parameters.

\begin{tabular}{cc}
\hline Adsorption process & Thermodynamic charactrisitss \\
\hline spontaneous & $\Delta G^{0}(-)$ \\
non spontaneous & $\Delta G^{0}(+)$ \\
exothermic & $\Delta H^{0}(-)$ \\
endothermic & $\Delta H^{0}(+)$ \\
affinity between adsorbent and adsorbate & $\Delta S^{0}(+)$ and $\Delta G^{0}(-)$ \\
no affinity between adsorbent and adsorbate & $\Delta S^{0}(+)$ and $\Delta G^{0}(+)$ \\
\hline
\end{tabular}

Table 4. Chemical characteristics of the expanded vermiculite by XRD.

\begin{tabular}{ccccc}
\hline \multirow{2}{*}{ Element } & \multicolumn{2}{c}{ Before washing } & \multicolumn{2}{c}{ After washing } \\
\cline { 2 - 5 } & Mass (\%) & Standard deviation (\%) & Mass (\%) & Standard deviation (\%) \\
\hline $\mathrm{C}$ & 27.01 & \pm 1.22 & 32.23 & \pm 1.18 \\
$\mathrm{~N}$ & 16.87 & \pm 2.04 & 0 & - \\
$\mathrm{O}$ & 33.33 & \pm 0.69 & 35.04 & \pm 0.63 \\
$\mathrm{Mg}$ & 4.15 & \pm 0.10 & 2.19 & \pm 0.09 \\
$\mathrm{Al}$ & 1.22 & \pm 0.22 & 2.13 & \pm 0.05 \\
$\mathrm{Si}$ & 7.48 & \pm 0.19 & 11.54 & \pm 0.11 \\
$\mathrm{P}$ & 3.34 & \pm 0.01 & 0 & - \\
$\mathrm{Ti}$ & 0.78 & \pm 0.16 & 3.7 & \pm 0.11 \\
$\mathrm{Cr}$ & - & - & 1.17 & \pm 0.11 \\
$\mathrm{Fe}$ & 5.82 & \pm 0.33 & 12.00 & \pm 0.41 \\
$\mathrm{Total}$ & 100 & & 100 & \\
\hline
\end{tabular}


results could be biased if the intent is to evaluate nitrogen removal using vermiculite as adsorbent.

\subsection{Modification of Expanded Vermiculite}

After the modification using $\mathrm{HCl} 2 \mathrm{~mol} / \mathrm{L}$, at 2 hours of contact time and $60^{\circ} \mathrm{C}$, it could be visually observed that the expanded vermiculite lost color and structural features. Results produced by Lopez-Gonzalez and BarrelRuiz [39] corroborate these observations. These authors found a total dissolution of the vermiculite and also reported obtaining a white silicate after modification using $\mathrm{HCl} 5 \mathrm{~mol} / \mathrm{L}$, at a 30 -minute contact time. It is worth mentioning that even using a lower concentration it was possible to observe a change in color of the gel formed as a result of the modification using $\mathrm{HCl} 2 \mathrm{~mol} / \mathrm{L}$.

After these observations tests with lower $\mathrm{HCl}$ concentrations $(1 \mathrm{~mol} / \mathrm{L} ; 0,1 \mathrm{~mol} / \mathrm{L})$ were carried out. The modification using $0.1 \mathrm{~mol} \mathrm{HCl} / \mathrm{L}$, at a 2-hour contact time at room temperature, produced the best modification condition. The treatment using this concentration allowed observing a slight loss of color whereas the vermiculite did not present structural loss.

In spite of having not been observed alterations in the vermiculite treated with $2 \mathrm{~mol} \mathrm{NaOH} / \mathrm{L}$, to compare results obtained for the modification with $\mathrm{HCl}$ and $\mathrm{NaOH}$ the treatment was also processed with 0.1 mol $\mathrm{NaOH} / \mathrm{L}$, at the same contact time, at room temperature.

Table 5 presents results produced by XRD for the chemical characterization of modified expanded vermiculite using $\mathrm{HCl}$ and $\mathrm{NaOH}$. These results allow pointing out that there was an increase of the mass percentage of $\mathrm{Al}$ and reduction of the percentage of $\mathrm{K}$ in the expanded vermiculite modified using $\mathrm{HCl}$. Thus, the observation that $\mathrm{K}$ was substituted by $\mathrm{Al}$ is corroborated by the results presented by Carter et al. [40], who observed the substitution of $\mathrm{K}$ by $\mathrm{Al}$ when the vermiculite was modified by $\mathrm{HCl}$. It was also possible to observe that the modification using $\mathrm{NaOH}$ produced the replacement of $\mathrm{K}$ by $\mathrm{Mg}$ and $\mathrm{Na}$ when vermiculite was modified using $\mathrm{NaOH}$. Results by Raman and Jackson [41] corroborate the results produced by this research. The authors also found out that, as a consequence of hydration, $\mathrm{K}$ ions were replaced by $\mathrm{Mg}$ and $\mathrm{Na}$ ions after treating vermiculite with a solution of $\mathrm{MgCl}_{2}$.

Regarding the competition between $\mathrm{K}$ and $\mathrm{NH}_{4}$ ions, when vermiculite was modified using $\mathrm{HCl}$ and $\mathrm{NaOH}$ it was observed a reduction in the percentage of the mass of $\mathrm{K}$. These results are confirmed by those of Barshad [14]. This author pointed out that the adsorption of $\mathrm{K}$ and $\mathrm{NH}_{4}$ were proportional to the cation exchange capacity. Thus, when $\mathrm{K}$ is removed there is an increase in the adsorption capacity of $\mathrm{NH}_{4}$.

Table 5. Chemical characteristics of expanded vermiculite by XRD.

\begin{tabular}{cccc}
\hline Component & Natural $^{*}$ & ${\text { Modified }(\mathbf{H C l})^{*}}^{*}$ & Modified (NaOH) $^{*}$ \\
$\mathrm{SiO}_{2}$ & 34.19 & 35.70 & 34.10 \\
$\mathrm{MgO}$ & 23.65 & 23.70 & 24.20 \\
$\mathrm{Al}_{2} \mathrm{O}_{3}$ & 11.32 & 12.00 & 11.20 \\
$\mathrm{Fe}_{2} \mathrm{O}_{3}$ & 9.03 & 9.20 & 9.70 \\
$\mathrm{Na}_{2} \mathrm{O}$ & 0.00 & 0.00 & 3.10 \\
$\mathrm{TiO}_{2}$ & 1.65 & 1.80 & 1.80 \\
$\mathrm{Cr}_{2} \mathrm{O}_{3}$ & 0.78 & 0.90 & 0.80 \\
$\mathrm{NiO}$ & 0.27 & 0.30 & 0.30 \\
$\mathrm{Cl}$ & 0.00 & 0.10 & 0.00 \\
$\mathrm{CaO}$ & 0.13 & 0.10 & 0.10 \\
$\mathrm{MnO}$ & 0.05 & $<0.10$ & 0.10 \\
$\mathrm{~V}_{2} \mathrm{O}_{5}$ & 0.02 & $<0.10$ & $<0.10$ \\
$\mathrm{SO}$ & 0.01 & - & - \\
$\mathrm{K}_{2} \mathrm{O}$ & 0.01 & - & - \\
$\mathrm{ZnO}$ & 0.01 & - & - \\
\hline
\end{tabular}

Note: ${ }^{*}$ Concentration in mass per mass percentage. 


\subsection{Adsorption Batch Tests}

Figure 3 presents the results produced for the assessment of ammonium nitrogen adsorption onto natural expanded and modified vermiculite.

As presented in Figure 3, after a 6-hour contact time the concentration of ammonium nitrogen decreased as the adsorption time increased. After 24 hours of experiment efficiencies of ammonium nitrogen adsorption onto expanded natural vermiculite, vermiculite modified by $\mathrm{HCl}$ and also by $\mathrm{NaOH}$ were $84 \%, 82 \%$ and $64 \%$, respectively. Therefore, it can be stressed that natural expanded vermiculite is the most appropriate adsorbent for the adsorption of ammonium nitrogen because it saves time and financial resources of the laboratory.

In all experiments, it was possible to observe that until 6 hours of contact time, approximately, there was a variation in the concentration of ammonium nitrogen. This variation can be related to the possibility of adsorption followed by desorption due to the functional characteristics of the expanded vermiculite.

\subsection{Langmuir and Freundlich Isotherms}

Table 6 and Table 7 present results produced for the determination of adsorption isotherms.

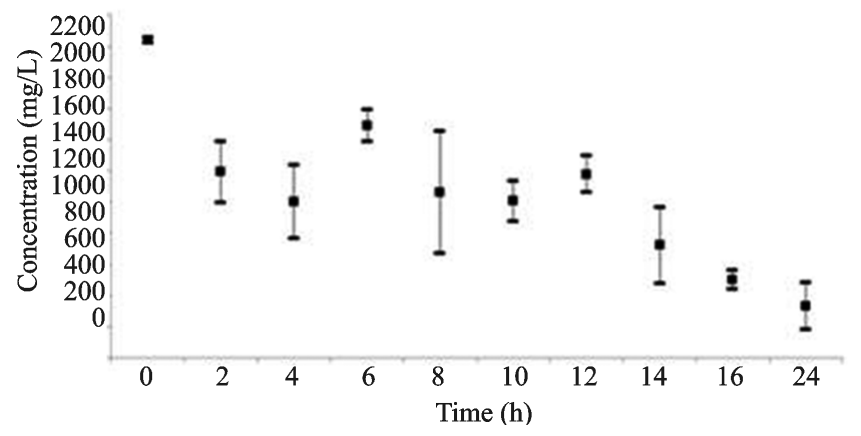

(a)

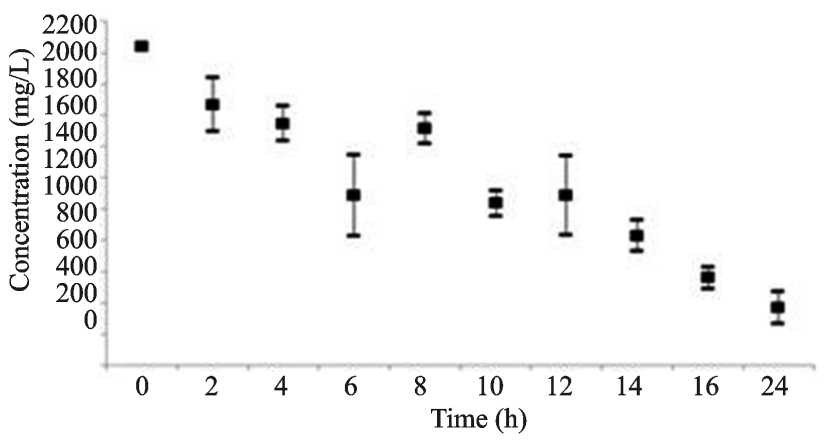

(b)

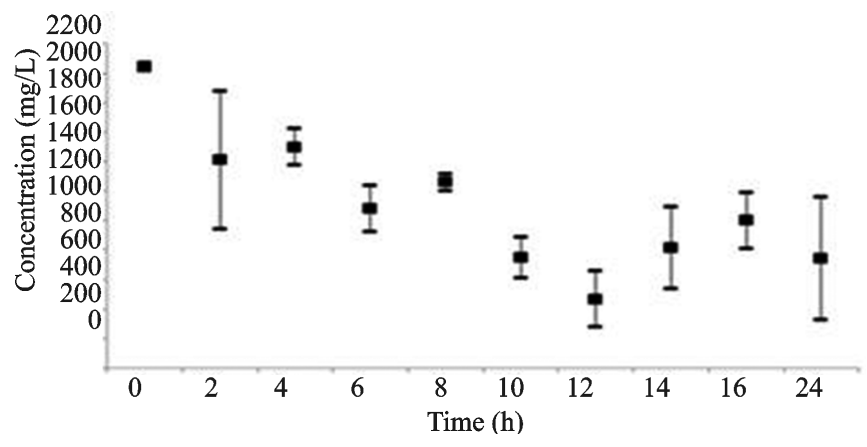

(c)

Figure 3. $\mathrm{N}^{-\mathrm{NH}_{3}}$ adsorption onto vermiculite: (a) natural expanded; (b) modified with $\mathrm{HCl}$; (c) modified with $\mathrm{NaOH}$. 
As it can be observed from the data presented in Table 6, the adsorption capacity increases with an increase in temperature.

In order to produce a more refined correlation and to estimate the parameters of the isotherms the experimental data were adjusted to the models of Langmuir (Equation (2)) and Freundlich (Equation (3)). Table 7 presents the values estimated for the adsorption isotherms of ammonium nitrogen onto expanded natural vermiculite.

According to the data presented in Table 7, it is possible to observe that the values of $R_{L}$ equaled the unity. These results suggest that the adsorption process is linear and indicates that the active sites are homogeneous in terms of energy and that there is no interaction amongst the adsorbed species [32]. As the results for the correlation coefficient $\left(R^{2}\right)$ for all temperatures were similar, it was necessary to apply the Sum of Squares (SS) statistical method to the equilibrium data (Table 8). The SS method provides a strong statistical argument because the lower the SS value, the better the adjustment of the data to the isotherm model.

According to the results it can be affirmed that the experimental data best fitted the Langmuir isotherm, in particular those produced at the temperatures $288 \mathrm{~K}$ and $296 \mathrm{~K}$. The Langmuir isotherm is monolayered and hence, only a fixed number of sites are accessible and available on the surface of the adsorbent. Furthermore, all sites present the same energy for adsorption [1].

Table 6. Adsorption capacity at $288 \mathrm{~K}, 296 \mathrm{~K}$ and $303 \mathrm{~K}$.

\begin{tabular}{cccc}
\hline Temperature $(\mathbf{K})$ & $\mathbf{2 8 8}$ & $\mathbf{2 9 6}$ & $\mathbf{3 0 3}$ \\
\hline Concentration $\left(\mathbf{m g N}-\mathbf{N H}_{3} / \mathbf{L}\right)$ & & $\mathbf{q}_{\mathrm{eq}}\left(\mathbf{m g N}-\mathbf{N H}_{3} / \mathbf{g}_{\text {vermiculite }}\right)$ & \\
\hline 130 & $0.11 \pm 0.01$ & $0.45 \pm 0.01$ & $0.63 \pm 0.01$ \\
340 & $1.57 \pm 0.16$ & $1.75 \pm 0.85$ & $1.39 \pm 0.66$ \\
760 & $3.52 \pm 0.35$ & $6.18 \pm 0.69$ & $7.04 \pm 0.25$ \\
1200 & $10.04 \pm 0.85$ & $12.09 \pm 0.16$ & $13.89 \pm 0.74$ \\
1700 & $13.24 \pm 1.67$ & $15.36 \pm 0.18$ & $16.00 \pm 0.50$ \\
\hline
\end{tabular}

Table 7. Model parameters of the Langmuir and Freundlich isotherms.

\begin{tabular}{cccccccc}
\hline Temperature (K) & \multicolumn{3}{c}{ Langmuir } & \multicolumn{3}{c}{ Freundlich } \\
\cline { 2 - 7 } & $\mathbf{R}^{\mathbf{2}}$ & $\mathbf{K}_{\mathbf{L}}$ & $\mathbf{R}_{\mathbf{L}}$ & $\mathbf{R}^{\mathbf{2}}$ & $\mathbf{K}_{\mathbf{F}}$ & $\mathbf{n}$ \\
\hline 288 & 0.95 & $3.7 \times 10^{-8}$ & 1 & 0.97 & $5.2 \times 10^{-4}$ & 0.74 \\
296 & 0.97 & $5.1 \times 10^{-8}$ & 1 & 0.98 & $2.9 \times 10^{-3}$ & 0.87 \\
303 & 0.95 & $3.6 \times 10^{-7}$ & 1 & 0.96 & $4.7 \times 10^{-3}$ & 0.91 \\
\hline
\end{tabular}

Note: $\mathrm{K}_{\mathrm{L}}=$ Langmuir constant; $\mathrm{R}_{\mathrm{L}}=$ equilibrium parameter; $\mathrm{K}_{\mathrm{F}}=$ Freundlich distribution coefficient; $\mathrm{n}=$ intensity of the adsorption process.

Table 8. SS values for the models and temperatures evaluated.

\begin{tabular}{cccc}
\hline \multirow{2}{*}{ Model } & \multicolumn{3}{c}{ Temperature (K) } \\
\cline { 2 - 4 } & $\mathbf{2 8 8}$ & $\mathbf{2 9 6}$ & $\mathbf{3 0 3}$ \\
\hline Langmuir & 0.39 & 0.35 & 0.59 \\
Freundlich & 0.56 & 0.41 & 0.61 \\
\hline
\end{tabular}

Table 9. Thermodynamics of the adsorption process.

\begin{tabular}{cccc} 
& \multicolumn{3}{c}{ Thermodynamic parameters } \\
Temperature $(\mathrm{K})$ & $\boldsymbol{\Delta} \boldsymbol{G}(\mathbf{k J} / \mathbf{m o l})$ & $\boldsymbol{\Delta H}(\mathbf{k J} / \mathbf{m o l})$ & $\boldsymbol{\Delta} \boldsymbol{S}(\mathbf{k J} / \mathbf{m o l})$ \\
\cline { 2 - 4 } & -6.0 & & \\
288 & -10.6 & 100.9 & 372.8 \\
303 & -11.5 & & \\
\hline
\end{tabular}




\subsection{Adsorption Thermodynamics}

Table 9 presents results on the thermodynamics conditions of the ammonium nitrogen adsorbed onto vermiculite.

As it can be observed, negative values were obtained for the Gibbs free energy $\left(\Delta G^{0}\right)$ and positive values for both the enthalpy $\left(\Delta H^{0}\right)$ and the entropy $\left(\Delta S^{0}\right)$ for the three temperatures studied. According to the literature [42]-[48] negative values confirm the viability and spontaneity of the adsorption process. Also according to the literature [49], the range between $-20 \mathrm{~kJ} / \mathrm{mol}$ and $0 \mathrm{~kJ} / \mathrm{mol}$ indicates that the interaction between the adsorbate and the adsorbent occurs via physical adsorption. The experimental data are consistent with the information provided by the results of the Langmuir isotherm to which the data best fitted.

On one hand, positive values for entropy indicate that the adsorption process is irreversible and stable, which reflects the affinity between the adsorbate and the adsorbent. On the other hand, positive values for enthalpy indicate the endothermic nature of the adsorption process, i.e., the adsorption capacity increases when there is an increase in temperature. Thus, the results presented in Table 6 allow pointing out that the nature of the adsorption of ammonium nitrogen onto expanded vermiculite is an endothermic process.

\section{Conclusions}

The results presented allow concluding that pre-washing of vermiculite is an important step prior to using it as an adsorbent and that it also releases adsorption sites. The observed interference can be due to the presence of impurities from the production process of extraction or can also be related to the conditions of storage. The presence of impurities, in particular the presence of nitrogen, can bias the results of the research, especially in the case of evaluating the removal of ammonium nitrogen from landfill leachate.

Regarding the modification of the expanded mineral, the best results produced were related to the concentration $0.1 \mathrm{~mol} / \mathrm{L}$ of both $\mathrm{HCl}$ and $\mathrm{NaOH}$. This concentration at a 2-hour contact time at room temperature allowed observing that there was no loss of either color or structural characteristics of the expanded vermiculite. However, the results of the adsorption test proved that the highest efficiency of ammonium nitrogen removal of $84 \%$ was produced using natural expanded vermiculite that was unmodified.

The results produced by XRD made it possible to observe that Al substituted $\mathrm{K}$ when the expanded vermiculite was modified using $\mathrm{HCl}$, whereas $\mathrm{Mg}$ and $\mathrm{Na}$ substituted $\mathrm{K}$ when the adsorbent was modified using $\mathrm{NaOH}$.

The use of the SS method allowed concluding that the experimental data best fitted the Langmuir isotherm. The conclusion on the linearity of the adsorption and the interaction amongst the adsorbed species was made possible by the observation of the $R_{L}$ values, which equaled the unit.

The values of the thermodynamic parameters, $\Delta G^{0}, \Delta H^{0}$ and $\Delta S^{0}$, indicate that the adsorption process of ammonium nitrogen onto natural expanded vermiculite is spontaneous and endothermic and that there is a high affinity between the adsorbent and the adsorbate. The results also allow concluding that the interaction between ammonium nitrogen and natural expanded vermiculite is favorable and occurs via physical adsorption.

Based on these results, it was demonstrated that the expanded vermiculite was an alternative adsorbent material, which was effective in the adsorption process, and that it could be used in the pre-treatment of wastewaters containing ammonium nitrogen.

\section{Acknowledgements}

This research was financially supported by FINEP_-Financier of Studies and Projects, CNPq-Brazilian Council for Scientific and Technological Development, and CAPES - Coordination for the Improvement of Higher Education Personel, Brazil.

\section{References}

[1] Tchobanoglous, G., Burton, F.L. and Stensel, H.D. (2003) Adsorption. In: Metcalf \& Eddy Inc., Ed., Wastewater Engineering: Treatment and Reuse, 4th Edition, McGraw-Hill, New York, 1138-1162.

[2] Walker, G.F. (1975) Soil Components: Inorganic Components. Springer-Verlag, New York.

[3] Minerals Zone: World Mineral Exchange (2014) Vermiculite. http://www.mineralszone.com/minerals/vermiculite.html

[4] Ugarte, J.O. Sampaio, J.A. and França, S.C.A. (2005) Rochas e minerais industriais: usos e especificações. Centro de Tecnologia Mineral, Rio de Janeiro. (In Portuguese)

[5] Ralf, J. (2014) Vermiculite. http://www.mindat.org/min-4170.html 
[6] Web Mineral (2014) Vermiculite. http://www.mindat.org/min-4170.html

[7] The Vermiculite Association (2014) Vermiculite Data. http://webmineral.com/data/Vermiculite.shtml\#.VXC1089VhBc

[8] Dupré Minerals (2014) What Is Vermiculite? http://www.dupreminerals.com/en/vermiculite/introduction

[9] How Products Are Made (2014) Vermiculite. Volume 6. http://www.madehow.com/Volume-6/Vermiculite.html

[10] Dolcater, D.L., Jackson, M.L. and Syers, J.K. (1972) Cation-Exchange Selectivity in Mica and Vermiculite. American Mineralogist, 57, 1823-1831.

[11] Ziper, C., Komarneni, S. and Baker, D.E. (1988) Specific Cadmium Sorption in Relation to the Crystal Chemistry of Clay Minerals. Soil Science Society of America Journal, 52, 49-53. http://dx.doi.org/10.2136/sssaj1988.03615995005200010009x

[12] Foscolos, A.E. (1968) Cation-Exchange Equilibrium Constants of Aluminium-Saturated Montmorillonite and Vermiculite Clays. Soil Science Society of America Journal, 32, 350-354. http://dx.doi.org/10.2136/sssaj1968.03615995003200030026x

[13] Abollino, O., Giacomino, A., Malandrino, M. and Mentasti, E. (2008) Interaction of Metal Ions with Montmorillonite and Vermiculite. Applied Clay Science, 38, 227-236. http://dx.doi.org/10.1016/j.clay.2007.04.002

[14] Barshad, I. (1954) Cation Exchange in Micaceous Minerals II: Replaceability of Ammonium and Potassium Vermiculite, Biotite and Montmorillonite. Soil Science, 78, 57-76. http://dx.doi.org/10.1097/00010694-195407000-00007

[15] Reinholdt, M.X., Hubert, F., Faurel, M., Tertre, E., Razafitianamaharavo, A., Francius, G., Prêt, D., Petit, S., Béré, E., Pelletier, M. and Ferrage, E. (2013) Morphological Properties of Vermiculite Particles in Size-Selected Fractions Obtained by Sonication. Applied Clay Science, 77-78, 18-32. http://dx.doi.org/10.1016/j.clay.2013.03.013

[16] Froehner, S., Machado, K.S. and Falcão, F. (2010) Adsorption of Dibenzothiophene by Vermiculite in Hydrophobic Form, Impregnated with Copper Ions and in Natural Form. Water, Air and Soil Pollution, 209, 357-363. http://dx.doi.org/10.1007/s11270-009-0204-8

[17] Xu, C.G., Ning, G.Q., Zhu, X., Wang, G., Liu, X.F., Gao, J.S., Zhang, Q., Qian, W.Z. and Wei, F. (2013) Synthesis of Praphene from Asphaltene Molecules Adsorbed on Vermiculite Layers. Carbon, 62, 213-221. http://dx.doi.org/10.1016/j.carbon.2013.05.059

[18] El-Bayaa, A.A., Badawy, N.A. and Abdalkhalik, E. (2009) Effect of Ionic Strength on the Adsorption of Cooper and Chromium Ions by Vermiculite Pure Clay Mineral. Journal of Hazardous Materials, 170, 1204-1209. http://dx.doi.org/10.1016/j.jhazmat.2009.05.100

[19] Liu, Y., Zheng, Y. and Wang, A.Q. (2010) Enhaced Adsorption of Methylene Blue from Aqueous Solution by Chitosan-g-poly (acrylic acid)/vermiculite Hydrogel Composites. Journal of Environmental Sciences, 22, 486-493. http://dx.doi.org/10.1016/S1001-0742(09)60134-0

[20] Katsou, E., Malamis, S. and Haralambous, K.J. (2011) Industrial Wastewater Pre-Treatment for Heavy Metal Reduction by Employing a Sorbent-Assisted Ultrafiltration System. Chemosphere, 82, 557-564. http://dx.doi.org/10.1016/j.chemosphere.2010.10.022

[21] Chen, Q.Q., Wu., P.X., Dang, Z., Zhu, N.W., Li, P., Wu, J.H. and Wang, X.D. (2010) Iron Pillared Vermiculite as a Heterogeneous Photo-Fenton Catalyst for Photocatalytic Degradation of Azo Dye Reactive Brilliant Orange X-GN. Separation and Purification Technology, 71, 315-323.

[22] Hango, T., Yoshino, S., Yamazaki, A., Yamazaki, A. and Satokawa, S. (2012) Mechanochemical Treatment of Vermiculite in Vibration Milling and Its Effect on Lead (II) Adsorption Ability. Applied Clay Science, 70, 74-78. http://dx.doi.org/10.1016/j.clay.2012.09.016

[23] Temuujin, J., Okada, K. and Okada, K.J.D. (2003) Preparation of Porous Silica from Vermiculite by Selective Leaching. Applied Clay Science, 22, 187-195. http://dx.doi.org/10.1016/S0169-1317(02)00158-8

[24] Cristiano, D.V., Campos, A.M. and Molina, R. (2005) Charge Reduction in a Vermiculite by Acid and Hydrothermal Methods: A Comparative Study. Journal of Physical Chemistry, 109, 19026-19033. http://dx.doi.org/10.1021/jp044437v

[25] Okada, K., Arimitsu, N., Kameshima, Y., Nakajima, A. and Mackenzie, M.J.D. (2005) Preparation of Porous Silica from Chlorite by Selective Acid Leaching. Applied Clay Science, 30, 116-124. http://dx.doi.org/10.1016/j.clay.2005.04.001

[26] Abate, G., Santos, L.B.O., Colombo, S.M. and Masini, J.C. (2006) Removal of Fulvic Acid from Aqueous Media by Adsorption onto Modified Vermiculite. Applied Clay Science, 32, 261-270. http://dx.doi.org/10.1016/j.clay.2006.02.004

[27] Okada, K., Arimitsu, N., Kameshima, Y., Nakajima, A. and Machenzie, K.J.D. (2006) Solid Acidity of 2:1 Type Clay Minerals Activated by Selective Leaching. Applied Clay Science, 31, 185-193. http://dx.doi.org/10.1016/j.clay.2005.10.014

[28] Nguyen, A.N., Reinert, L., Lévêque, J.M., Beziat, A., Dehaudt, P., Juliaa, J.F. and Duclaux, L. (2013) Preparation and 
Characterization of Micron and Submicron-Sized Vermiculite Powders by Ultrasonic Irradiation. Applied Clay Science, 72, 9-17. http://dx.doi.org/10.1016/j.clay.2012.12.007

[29] Zhang, H.L., Xu, H.B., Wang, X.L. and Yu, J.Y. (2013) Microestructures and Thermal Aging Mechanism of Expanded Vermiculite Modified Bitumen. Construction and Building Materials, 47, 919-926. http://dx.doi.org/10.1016/j.conbuildmat.2013.05.099

[30] Yang, X.Y. and Al-Duri, B. (2005) Kinetic Modeling of Liquid-Phase Adsorption of Reactive Dyes on Activated Carbon. Journal of Colloid and Interface Science, 287, 25-34. http://dx.doi.org/10.1016/j.jcis.2005.01.093

[31] Chand, P., Shil, A.K., Sharma, M. and Pakade, Y.B. (2014) Improved Adsorption of Cadmium Ions from Aqueous Solution Using Chemically Modified Apple Pomace: Mechanism, Kinetics, and Thermodynamics. International Biodeterioration and Biodegradation, 90, 8-16. http://dx.doi.org/10.1016/j.ibiod.2013.10.028

[32] Panuccio, M.R., Sorgonà, A., Rizzo, M. and Cacco, G. (2009) Cadmium Adsorption on Vermiculite, Zeolite and Pumice: Bath Experimental Studies. Journal of Environmental Management, 90, 364-374. http://dx.doi.org/10.1016/j.jenvman.2007.10.005

[33] Castilla, C.M. (2004) Adsorption of Organic Molecules from Aqueous Solutions on Carbon Materials. Carbon, 42, 8394. http://dx.doi.org/10.1016/j.carbon.2003.09.022

[34] Varshney, K.G., Gupta, A. and Singhal, K.C. (1995) The Adsorption of Carbofuran on the Surface of Antimony (v) Arsenosilicate: A Thermodynamic Study. Colloids and Surfaces A: Physicochemical and Engineering Aspects, 104, 710. http://dx.doi.org/10.1016/0927-7757(95)03258-F

[35] Srivastava, V.C., Swamy, M.M., Mall, I.D., Prasad, B. and Mishra, I.M. (2006) Adsorptive Removal of Phenol by Bagasse Fly Ash and Activated Carbon: Equilibrium, Kinetics and Thermodynamics. Colloids and Surfaces A: Physicochemical and Engineering Aspects, 272, 89-104. http://dx.doi.org/10.1016/j.colsurfa.2005.07.016

[36] Rajoriya, R.K., Prasad, B., Mishra, I.M. and Wasewar, K.L. (2007) Adsorption of Benzaldehyde on Granular Activated Carbon: Kinetics, Equilibrium, and Thermodynamic. Chemical and Biochemical Engineering Quarterly, 21, 219-226.

[37] Dabrowski, A. (2001) Adsorption-From Theory to Practice. Advances in Colloid and Interface Science, 93, $135-224$. http://dx.doi.org/10.1016/S0001-8686(00)00082-8

[38] APHA, AWWA and WEF (1998) Standard Methods for the Examination of Water and Wastewater. 20th Edition, APHA, AWWA and WEF, Washington DC.

[39] Lopez-Gonsalez, J. de D. and Cano-Ruiz, J. (1959) Surface Changes of Vermiculite by Acid and Thermal Treatment. Clays and Clay Minerals. In: Swineford, A., Ed., Proceedings of the Sixth National Conference on Clays and Clay Minerals, Monograph No. 2, Earth Science Series, Pergamon Press, London, 399-405.

[40] Carter, D.L., Haward, M.E. and Young, J.L. (1963) Variation in Exchangeable K and Relation to Intergrade Layer Silicate Minerals. Proceedings Soil Science Society of America, 27, 27-283.

[41] Raman, K.V. and Jackson, M.L. (1964) Vermiculite Surface Morphology. Clays and Clay Minerals, 12, 423-429.

[42] Karadag, D., Tok, S., Akgul, E., Turan, M., Ozturk, M. and Demir, A. (2008) Ammonium Removal from Sanitary Landfill Leachate Using Natural Gördesclinoptilolite. Journal of Hazardous Materials, 153, 60-66. http://dx.doi.org/10.1016/j.jhazmat.2007.08.019

[43] Islam, M. and Patel, R. (2010) Synthesis and Physicochemical Characterization of Zn/Al Chloride Layered Double Hydroxide and Evaluation of Its Nitrate Removal Efficiency. Desalination, 256, 120-128. http://dx.doi.org/10.1016/j.desal.2010.02.003

[44] Tu, Y.J., You, C.F. and Chang, C.K. (2012) Kinetics and Thermodynamics of Adsorption for Cd on Green Manufactured Nano-Particles. Journal of Hazardous Materials, 235-236, 116-122.

[45] Chen, Y.-C. and Lu, C. (2014) Kinetics, Thermodynamics and Regeneration of Molybdenum Adsorption in Aqueous Solutions with NaOCl-Oxidized Multiwalled Carbon Nanotubes. Journal of Industrial and Engineering Chemistry, 20, 2521-2527. http://dx.doi.org/10.1016/j.jiec.2013.10.035

[46] Liu, W., Yin, P., Liu, X.G., Dong, X.Q., Zhang, J. and Xu, Q. (2013) Thermodynamics, Kinetics, and Isotherms Studies for Gold (III) Adsorption Using Silica Functionalized by Diethylenetriamine-Methylene-Phosphonic Acid. Chemical Engineering Research and Desing, 91, 2748-2758. http://dx.doi.org/10.1016/j.cherd.2013.05.003

[47] Alshameri, A., Ibrahim, A., Assabri, A.M., Lei, X.R., Wang, H.Q. and Yan, C.J. (2014) The Investigation into the Ammonium Removal Performance of Yemeni Natural Zeolite: Modification, Ion Exchange Mechanism, and Thermodynamics. Powder Technology, 258, 20-31. http://dx.doi.org/10.1016/j.powtec.2014.02.063

[48] Yang, J.B., Yu, M.Q. and Qiu, T. (2014) Adsorption Thermodynamics and Kinetics of Cr (VI) on KlP210 Resin. Journal of Industrial and Engineering Chemistry, 20, 480-486. http://dx.doi.org/10.1016/j.jiec.2013.05.005

[49] Yu, Y., Zhuang, Y.-Y. and Wang, Z.-H. (2001) Adsorption of Water-Soluble Dye onto Functionalized Resin. Journal of Colloid and Interface Science, 242, 288-293. http://dx.doi.org/10.1006/jcis.2001.7780 